\title{
Comment on "Tuberculosis in Northeastern Brasil (2001-2016): trends, clinical profile, and prevalence of risk factors and comorbidities"
}

Divanise Suruagy Correia

1. Profa. Titular - Faculdade de Medicina -FAMED, Universidade Federal de Alagoas - UFAL, Maceió, AL, Brasil

Tuberculosis (TB) is an infectious disease caused by any of the species that make up the mycobacterium tuberculosis complex. Historically it represents a phenomenon that has affected illustrious figures such as writers, poets, artists, and kings. Thus, since ancient times, the disease has represented a public health problem difficult to be fought. Currently, it represents one of the 10 leading causes of death and the leading cause when a single infectious agent is considered, more than HIV/Aids ${ }^{1}$.

Global estimates indicate that approximately 10 million people have fallen ill due to TB only in 2018 alone, with a varying disease burden between countries $^{2}$. In that same year, the disease caused 1.2 million deaths among HIV-negative individuals and over 251,000 among those who are HIV-positive ${ }^{3}$. It is worth highlighting that these numbers, at a global level, have remained stable in recent years.

The burden of disease worldwide led the World Health Organization to define, for 2016-2020, three lists of priority countries, each one comprising 30 nations: 1 . Countries with the highest burden of disease; 2. Priority countries for multiple drug resistance; and 3. Priority countries due to coinfection by HIV (TB-HIV). Brasil was included in two of these lists: In the $2 \mathrm{O}^{\text {th }}$ position regarding the burden of disease, and in the $19^{\text {th }}$ position regarding TB-HIV coinfection ${ }^{4}$.

In 2018 alone, the country registered nearly 72,788 new cases of the disease, with an incidence rate of $34,8 / 100$ thousand inhabitants. Of these, 19,075 cases were in the Northeast region of Brasil, which ranked in second regarding the absolute number of new cases, third in incidence coefficient (33.1/100,000), second in postneonatal mortality due to the disease $(2.6 / 100,000)$, and third in retreatment $(15.9 \%)^{4}$.

This scenario demonstrates the need for constant surveillance of tuberculosis in the Northeast of Brasil, both at the municipal ${ }^{5}$, state, ${ }^{6}$, and regional ${ }^{7}$ levels. In the study by Souza et al. ${ }^{7}$, the authors analyze the temporal trend of the disease and the prevalence of associated comorbidities and factors. One should emphasize the reduction in the incidence rate of the disease in 2001-2016, with an annual decrease 
of $-2.3 \%$ (44.8/100,000 in 2001 and 30.92/100,000 in 2016).

In addition, in the study in question rates are substantially in the male population, whose annual percentage of reduction is much lower than that observed in the female population $(-2.37 \%$ and $4.18 \%$, respectively), which makes us reflect on the importance of the males in maintaining the chain of transmission of the disease in the region, accounting for $63.53 \%$ of the cases registered in 2001-2016 ${ }^{\mathbf{7}}$.

But what should we expect in the coming years? Which factors may be associated with an increased number of patients starting from 2016 in Brasil? Was is it the context of economic crisis? The expanded offer of diagnosis? More services available? These and other questions deserve the attention of Brazilian researchers.

\section{REFERENCES}

1. Brasil. Ministério da Saúde. Guia de Vigilância em Saúde. Brasília: Ministério da Saúde; 2017

2. World Health Organization. Global tuberculosis report 2015 (WHO/HTM/TB/2015.22). Geneva: World Health Organization; 2015. [cited 2020 Fev 28]. Available from: https://apps.who. int/iris/bitstream/handle/10665/191102/9789241565059_eng. pdf;jsessionid=257E179B7641F5CE7FD14BEF18488436? sequence=1

3. Uplekar M, Weil D, Lönnroth $\mathrm{K}$, Jaramillo E, Lienhardt C, Dias HM, et al. WHO's new end TB strategy. Lancet. 2015;385(9979):1799-801.

4. Brasil. Ministério da Saúde. Secretaria de Vigilância em Saúde. Boletim Epidemiológico 09. Brasil livre da Tuberculose: evolução dos cenários epidemiológicos e operacionais da doença. Brasília: Ministério da Saúde;2019.

5. Souza CDF, Matos TS, Santos VS, Santos FGB. Tuberculosis surveillance in an endemic area of northeastern Brasil. What do the epidemiological indicators reveal? J Bras Pneumol. 2019;45(2):e20180257.

6. Santos FGB, Paiva JPS, Araújo EMCF, Leal TC, Souza CDF, Duailibe FT. Tuberculosis in the state of Alagoas: spatial and temporal analysis between 2010 and 2015. O Mundo da Saúde. 2019;43(1):129-50.

7. Souza CD, Brito AB, Magalhães WB, Paiva IPS, Leal TC, Silva LF, et al. Tuberculose no Nordeste do Brasil (2001-2016): tendência, perfil clínico e prevalência de fatores de risco e comorbidades associadas. Rev Assoc Med Bras. 2020;66(9):1196-1202. 